RESEARCH ARTICLE

\title{
A Stored-Products Revolution in the 1st Millennium BC
}

\author{
Andrew Bevan
}

Keeping plants and animals beyond their natural shelf life is a central human challenge, both as a matter of immediate survival and for the social and economic opportunities that stored foods offer. Understanding different food storage and preservation strategies in the past is key to a whole series of other research agendas, but remains challenging, not least because the evidence is patchy and hard to interpret. The paper below joins growing efforts to address this longestablished challenge and surveys a host of changes in preservative treatments and food storage facilities across the Mediterranean and temperate Europe during the $1^{\text {st }}$ millennium BC. While in most cases, the observed changes have a deeper prehistoric pedigree, nevertheless their mutually-reinforcing intensification at this time constitutes a real revolution, with far-reaching consequences.

\section{Introduction}

Food-keeping underwrites human history. It has always been a major factor, whether we are concerned with the daily demands of household survival, with broad trends in population growth, decline or urban concentration, with the co-evolutionary trajectories of humans, plants, animals and insects, with economic specialisation and commercial exchange, or with the politics of human labour relations, gender roles and social inequality (to name but a few). Unsurprisingly, therefore, a welter of recent research (e.g. Balbo 2015; Bogaard 2017; Fuller and Stevens 2017; Manzanilla and Rothman 2016; Martin 2019; Panagiotakopulu and Buckland 2017) demonstrates renewed enthusiasm for this topic and for earlier pioneering work (e.g. Gast and Sigaut 1979 and

UCL Institute of Archaeology, London WC1H OPY, $\mathrm{GB}$

a.bevan@ucl.ac.uk following). Drawing inspiration from these efforts, I would like to look briefly at some important trends in food preservation and storage that are part of a wider Iron Age 'bigbang' across Eurasia, focusing below mainly on the westerly portions of this phenomenon, from the shores of the Mediterranean to the forests and plains of northern Europe (Broodbank 2013: 506-592; Buchsenschutz 2015; Fernández-Götz and Krausse 2016). This large, environmentally and culturally varied region sees dramatic transformations in food practices during the 1st millennium $\mathrm{BC}$, with long-lasting consequences that are well-worth a brief but integrated treatment.

Food storage is a slippery archaeological topic. Ethnography, written documents and imagery all attest to a huge range in foodkeeping practices, with regard to the spaces used (e.g. caves, pits, built silos, garrets, cellars, bedrooms, barns, or the open air), the accompanying equipment (e.g. bins, baskets, barrels, sacks, suspension hooks, jars 
or chests), the options for direct preservative treatment (e.g. rendering, salting, waxing, drying, smoking, pickling, parboiling, fermenting or pressing) and various initially counter-intuitive, storage risk mitigation strategies (e.g. reciprocal food-giving within communities, food stored on-the-hoof, food security through inter-regional trade). Archaeology has a central role to play in documenting and explaining this diversity, and a cross-disciplinary obligation to foster longitudinal comparison. However, it is also obvious that not all of the above categories will be evenly represented archaeologically (Groenewoudt 2015; Peña-Chocarro et al. 2015), and because human communities often switch flexibly among different short, medium and long-term storage options, our view of them is still often just a speculative squint, despite some increasingly innovative investigative methods.

Given these caveats, Europe in the 1st millennium $\mathrm{BC}$ offers a privileged vantage, with a rich mix of artefacts, micro-flora and -fauna, residues, above-and-below ground structures, written words, images and landscapes. Beyond the well-known move from bronze to iron implements, there is also a much wider set of changes in the 1 st millennium BC. For example, Phoenician and Greek colonisation of the central and western Mediterranean ushers in the final stages of a basin-wide expansion in the production and consumption of wine, oil and other products, alongside an infrastructure for handling and shipping them (of which more below). Thereafter, the whole Mediterranean littoral becomes a single fiscal entity under Rome, with all that meant in terms of a more unified world of taxation, state mobilisation and speculation in foodstuffs. North of the Alps, the first settlement nucleations that might justify the term 'urban' appear, and while there remains intense debate about the degree to which these urban trends were independent of, or responsive to, Mediterranean ones, there is unequivocal evidence here too for people and food products now being mobilised at a considerable scale.
To reiterate, within a period of rapid change, this paper will explore the enabling role of stored-products, those portions of edible plants and animals that humans have worked hard to endow with shelf-lives beyond the biologically-expected: the cured meat kept hanging from the rafters, the cask or jar of wine kept in a cellar for decades, the grain kept in a pit for the spring-sowing, to sell at the right price or to grind later for consumption. While what is at stake in creating such provisions - for the short, medium or long-term - is basic food security and human survival, the results are nevertheless often a series of distinctive preserved products and striking storage facilities, as well as altered landscapes, seasonal activities and human roles, new kinds of collective action and new or increased capacities for individual speculation. Most of the products and facilities discussed below had good antecedents in the Neolithic and Bronze Age (or indeed earlier), but their marshalling, mixing and monetising in the 1st millennium BC was different, and together such newly-systematic practices profoundly altered the scale and scope of European and Mediterranean societies for the longer term.

\section{Marketing old cures}

The history of preservative food treatments stretches back to circumstantial but plausible evidence from the Palaeolithic, and then increasingly certain and sophisticated examples from the Mesolithic, Neolithic and Bronze Age. By the beginning of the Roman empire, various writers outline a bewildering array of preservative methods and products (Thurmond 2006) and it is tricky, then, to assess how gradual or punctuated is the intervening trajectory of change. However, one area where we can get a good sense of changing tempo is the salting of foods. Salt procurement was important from at least the Neolithic, as the new emphasis on cereals made deliberate addition of salt to a household diet a physiological necessity. Salt could be collected after solar evaporation on rocky coastlines or near lagoons (as often favoured 
in the Mediterranean), by mining the mineral (with practical challenges and mountainous localities quite similar to stone and metal mining), and via forced evaporation (simple pouring of brine onto a frame over a fire, more elaborate briquetage in pottery vessels or even more elaborate furnaces; see Brigand and Weller 2015; Harding 2013; Kinory 2012). The 1st millennium BC sees a sharp increase in the intensity and sophistication of salt production efforts: first, salt-mining becomes far more intensive at Hallstatt in the Austrian Alps (Daire 2003; Harding 2013: 67-85), and this is probably one of several reasons (others being increased mobilisation of local cereal and livestock surpluses and control of trade routes) for the appearance of large fortified settlements and elaborate tumulus burials across an arc from Burgundy to Bohemia (600-400 BC, Fernández-Götz 2018). On both the coasts of western Europe and at a few inland brine sources, there was also industrial-scale investment in furnace-enabled briquetage. Similarly, in the Mediterranean, Rome had already established a saltworks at Ostia by the later 7th century BC and a key early trans-Apennine route from the city was the Via Salaria (Rickman 1980: 28). In western Sicily and southwestern Iberia, new saltworks appear during the period of Phoenician colonisation and by the Roman period salt-marshes were also the focus of industrial exploitation (Morère 2013).

Salt has been crucial in three ways for preserving food (Chapman and Gaydarska 2003): (a) for dehydrating and protecting meat or fish, (b) for making butter and certain cheeses, and (c) for sustaining ruminant herds (hence on-the-hoof stores of dairy or meat). Of these, the treatment of meat and fish stands out as particularly relevant to the expanding food horizons and markets of the 1st millennium BC. Roman writers such as Strabo and Varro comment on the quality of Gallic and northern Spanish salted hams and mention exports to Rome (Rzeźnicka, Maciej Kokoszko and Jagusiak 2014; also Maltby 2006). By the 5th century BC, western
Sicilian and southern Iberian saltworks had prompted the local fish industry to switch from fairly general inshore catches to specialisation in bluefin tuna (Carusi 2008; Morales-Muñiz and Roselló Izquierdo 2008). Trade duly developed both in salted fish portions and salty liquified fish products, packaged in specifically-designed amphoras and shipped from the Straits of Gibraltar to as far east as Greece. By the 1st century AD, the high-volume trade in preserved fish foods nicely captures a flashy world of food globalisation, with complicated market mechanisms (i.e. varying prices, suppliers, intermediaries, consumers), high vertical and horizontal product differentiation (i.e. different quality grades and kinds), very attenuated patterns of distribution (i.e. a trade both in finished products and unfinished salted components that were further manipulated or adulterated on arrival) and end-consumers with only very limited understanding of the overall supply chain (Curtis 1991; Grainger 2018).

A final, more speculative comment relates to the development of storable milk-based products such as bog butter or hard cheese. While Andrew Sherratt (1981) made the attractive suggestion some time ago that dairying was part of a 'secondary products revolution' and not necessarily part of initial European and Mediterranean Neolithics, subsequent evidence increasingly implies that at least certain dairy products were present from the start (Evershed et al. 2008; Itan et al. 2009; Salque et al. 2013). That said, it is still worth speculating about whether later changes in practice and know-how may have extended the shelf life of dairy products, beyond well-known storage of milk 'on the hoof'. For instance, despite their probable Bronze Age beginnings, a large proportion of 'bog butter' finds from Ireland and northern Europe date to the Iron Age from ca. 400 BC onwards (with the importance or not of salting in this process still being unclear: Cronin et al. 2007; Smyth et al. 2019). Likewise, traditions of hard cheese production may have only become more important in the 1st millennium BC (Pearce 2016), with grateable 
cheeses mentioned in Homer ([1924] Iliad 11.638-640; also Ridgway 1997) and, later, Roman writers also discussing hard cheeses that might keep for up to a year and that were exported up to $1000 \mathrm{~km}$ from southern France and the Alps to Rome (e.g. Pliny [1940] Historia Naturalis 11.96-97; Columella [1954] De Re Rustica 8.8). The latter cheese-exporting Alpine regions not only had good access to salt which was part of the production process, but also provide paleoenvironmental evidence for an intensification of summer-time, high-altitude pasturing from the start of the 1st millennium BC (or a few centuries before). In other words, here and perhaps in some other parts of Europe, we should consider the possibility that whole landscapes and ways of life were being reconfigured by the development of newly-storable pastoral resources (Carrer et al. 2016; Giguet-Covex et al. 2014; Pearce 2016).

\section{Working with the grain}

Cereals have been the bedrock of many European and Mediterranean diets since the Neolithic, and storing cereals, in the face of various potential threats, has always been a fundamental challenge. Very briefly, two main approaches to keeping grain in any quantity for the medium to longer term are: (1) above ground, ventilated buildings (barns, raised granaries, other raised platforms) or air-tight, often-below-ground structures (primarily subterranean storage pits, but also certain kinds of sealed above-ground store; see especially Gast and Sigaut 1979). Beyond this distinction, the size, clustering and placement of storage facilities tells us much about changing risks and opportunities for different communities through time, as do other details observable in the archaeological record.

Here I want to focus fairly strictly on just a few significant changes in the 1st millennium BC. For example, while clay storage jars, bins, silo-pits and magazines were important features of Bronze Age food storage in Greece, a significant change from $500 \mathrm{BC}$ onwards was the emergence of larger forms of stone-built public granary, at sites such as Eleusis (where the 'first-fruits' of the Attic cereal harvest were dedicated to Demeter) or the Athenian Agora (where a 4th-century BC law makes provisions for storing an in-kind grain tax) or at Morgantina in Sicily where two elongated buildings probably housed a grain tax levied by the 3rd-century BC king of Syracuse (Stroud 1998; Walthall 2015). Not all of these efforts are of a piece in terms of their intentions, but overall, there is an uptick in statepromoted (if often privately implemented), monumental and ideologically-charged efforts to secure civic grains supplies and to control prices, (Casson 1954; Garnsey 1988), these all being harbingers of even larger initiatives in the following Roman period.

Key to the mobilisation of grain surpluses at this scale was maritime shipping and, despite one or two fascinating Bronze Age experiments, it is only in the 1st millennium BC that we see the truly systematic provisioning of certain favoured Mediterranean cities with grain by sea (e.g. Alston and van Nijf 2008), enabling them to grow far larger than they otherwise could, but at considerable economic and political risk. Such efforts ultimately underwrote the large size of Classical Athens, at least half of whose grain supply was imported (from the Black Sea and the central-western Mediterranean: Moreno 2007), and thereafter it supported Rome (with grain from Sicily, Sardinia, north Africa and eventually also Egypt), with the latter city reaching an estimated million inhabitants by the end of the 1st millennium BC. Careful storage of the previous year's harvest so that it could be shipped at the right time (often late spring/early summer) was a crucial part of this overall practice.

In temperate Europe two forms of cereal storage stand out amongst a range of alternatives (for the latter, e.g. Holzer and Stadler 2008; Bossard 2019): the post-granary and the silo-pit. The first of these has observable roots in the mid-2nd millennium BC (e.g. Arnoldussen 2008: 236-243; Gent 1983), and was a small hut (often 4-12m2) on four 
or more stilts (often with rat-guards) covered by a pitched roof, with walls that sometimes were partially open to allow ventilation. Post-granaries are often visible archaeologically as no more than a set of post-holes, so their identification often needs further circumstantial support. Furthermore, in certain regions, similar structures may have existed where the raised stilts were simple pads or runners (rather than sunken posts), and therefore may no longer be visible to us today. In any case, both ethnographically and archaeologically, such small raised granaries were multi-purpose, rapid-access storage structures, used for a variety of foods, farm equipment etc. but were perhaps most closely associated with the harvesting and laying up cereal ears (rather than full cleaned grains, hence spicarium in late Latin for this kind of granary, deriving from spica = ear, and espighieros for the raised granaries that survive up to the present day in Portugal and north-west Spain: Sigaut 1989). The silo-pit by contrast was a cylindrical or bell-shaped hole in the ground that could preserve grain in an air-tight environment. It is made as dry as possible before closing, and the ensuing chemical reactions leads to fermentation of the outer layer of grain in the pit which kills any existing pests and protect the vast majority of the contents from further decay (Gast and Sigaut 1979). Properly-prepared pits are very effective grain stores, and in certain soil conditions can keep grain for many years and/or be re-used many times, but they tend to require complete emptying once opened and, like post-granaries, their traces can sometimes be mis-identified (both because pits were also made for other reasons and because silo-pit fills rarely relate to their primary function). Silo-pits are a commonplace feature both of the Mediterranean and of temperate Europe, from the Neolithic to the near present, although their exact construction and popularity varies according to local soils, humidity, water table, crop choices and cultural traditions.

One general feature of post-granaries and pit storage worth emphasising is that both types can be found in clusters of tens, hundreds or even thousands at a given site (e.g. Figure 1a-b; Deffressigne, Landolt and Gransar 2017; Van de Noort, Chapman and Collis 2007). Sometimes these concentrations are on their own close to likely agricultural fields, sometimes next to lowland settlements or hillforts (Gent 1983; van der Veen and Jones 2006). In Germany and Bohemia, there is an increase in the number and clustering of silo-pits visible in the early years of the 1st millennium, if not before (e.g. Biederer 2018; Unger and Pecinovská 2015), but across temperate Europe as a whole, the period $500-200 \mathrm{BC}$ is perhaps the most salient, with many striking examples of storage nucleation, sometimes bounded by large enclosures. A further interesting point with pit groups is that a minority of them are often re-used for the rather odd deposition of humans or animals (in different regions: for formal graves, disordered articulated skeletons, disarticulated remains, as singletons or in groups), and seemingly thoughtful choices of artefacts (Bradley 2002; Cunliffe 1992; Delattre and Auxiette 2018; Delattre et al. 2000; Le Brun Ricalens 2014; see also Jeunnesse 2010). Ethnographic evidence for village accidents at silo-pits (people or animals falling in and dying), opportunistic body or refuse disposal in them, and their repurposing in various other ways urges great caution in interpreting their re-use for burial as always purposive and structured (Kunz 2004: 91-92). However, the funerary patterning remains sufficiently compelling in some instances, and combines well with other evidence such as possible granary-shaped cremation urns (Figure 1c; Sabatini 2007), to suggest that storage structures were indeed often deliberately used for burial or sacrifice, providing fertile social metaphors (e.g. for life-death cycles) and/or mechanisms for handling certain members of the community (e.g. classifying, disposing of, commemorating or disciplining them, whether as men, women, very old, very young, community outsiders, war captives, possible convicts or slaves). 


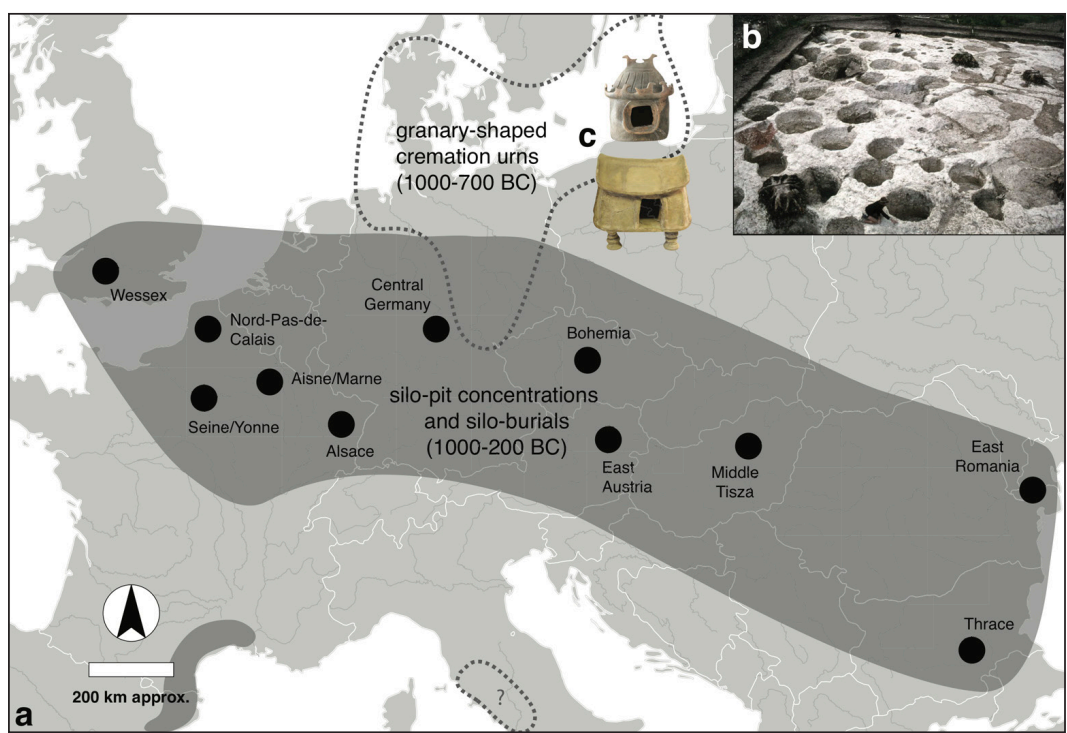

Figure 1: Silo-pits and post-granaries: (a) a band across temperate Europe of silo-pit concentrations and re-used silo-pits with burials, along with a northern distribution of Late Bronze Age 'house' urns that probably imitate granaries (selected sources are: Ailincăi 2015; Bradley 2002; Delattre et al. 2000; Garcia 1997; Griebl et al. 2017; Király et al. 2013; Landolt et al. 2010; Le Brun Ricalens 2014; Unger and Pecinovská 2015; Van Oyen 2019), (b) a concentration of silo-pits inside the hillfort at Danebury, UK (courtesy of Institute of Archaeology, Oxford University), and (c) two examples of 'house' urns from Saxony-Anhalt and Pomerania (Sabatini 2007: pls. 45.1, 42.6, with permission). Note that silo-pits are certainly also found south of the shaded area (e.g. in the Mediterranean Europe), but not in the same concentrations in this period (Figure: A. Bevan, with image permissions as above).

In any case, the challenge of such concentrated pit distributions (returning now to their inferred primary role for food storage) is to unpick what they might mean. Are silo-pit clusters, then, evidence for population growth or for population decline, for collective pooling by ordinary farming communities or for individual elite hoarding, for taxation in-kind or for its absence/avoidance, for flexible adaptation to local soils or for inherited cultural traditions irrespective of environment, for ritual or for basic subsistence, for protective impulses in times of trouble or for confident speculation with a view to nearby markets? In fact, while there are undoubtedly varying reasons, it is tempting to conflate several of these possibilities, and suggest that silo-pit concentrations are often found in highly-transitional phases (the Chasséen/Michelsberg Neolithic, Middle Iron Age or Early Medieval periods in Europe spring to mind), at historical moments of both physical human mobility and incipient population or settlement growth, both emerging social inequality and forms of community solidarity. Indeed, clusters of pits or small post-granaries were ways to push otherwise household-scale technologies to their limit, fostering inherent tensions between collective action and individual co-option. As a phenomenon, their peak is often for only a century or two in any given region, sometimes with accompanying shifts therein from many smaller-sized examples to fewer largersized ones, but they usually then either return to more dispersed arrangements or give way to yet larger, above-ground structures such as barns and warehouses. There are also sometimes switching behaviours through time, between clusters of pits and clusters of above-ground structures in the same site or region, suggesting changing 
priorities of accessibility and conspicuousness (Bossard 2019).

Starting earlier in some places, but increasingly clear during the 1st century BC with the expansion of Rome, is a move away from using silo-pits for storage towards larger post-granaries (e.g. 6-, 9- or 12-poster) and eventually above-ground Roman warehouses (horrea; Haselgrove 2007: 503; Van Oyen 2019). The latter warehouses were a relatively late arrival even in Rome itself, appearing most likely as part of the fraught politics of Gracchan grain reform (Rickman 1971: 149150) and also featuring as part of a wider elite moral discourse about appropriate ways to store and display surplus (Van Oyen 2015; Woolf 1990). In any case, both in Rome and across the emerging empire, horrea provided the pre-conditions for massively increased bulk exchange of food surpluses, whether by private landowners, by the military or for enormous state disbursements such as Rome's citizen grain ration (Mattingly and Aldrete 2000).

So the rural landscapes of parts of the Mediterranean and western Europe were being re-shaped during the latter part of the 1st millennium BC, often with a view to supplying cereals to much larger emerging markets, especially by river and by sea. In temperate parts of Europe, with the emergence of the larger towns known as oppida in the 2nd and 1st centuries BC, storage structures counter-intuitively become far less visible in the wider countryside, especially silo-pits (Bossard 2019; Gransar 2000: 293-294), but the impression is that: (a) a few concentrations of post-granaries remain, (b) cereal surpluses were being mobilised quickly and sent to newly emerging urban markets in ways that made silopits unnecessary or undesirable, and (c) perhaps that new timber-frame methods at these more urban oppida sites may have provided above ground store-rooms that are harder to spot archaeologically (Gransar 2003; Péfau 2017; Zech-Matterne, Malrain and Auxiette 2013).

Related to these changes are also shifts in how cereals were consumed. While bread has a very old Near Eastern pedigree, cereals eaten in the form of a porridge had probably been the dominant mode in the Neolithic and Bronze Age of many areas. In contrast, bread sees increasing popularity during the 1 st millennium BC, both in the Mediterranean and in parts of temperate Europe. Pliny ([1950] Historia Naturalis 18.28) offers a nice anecdote to the effect that bread-making was a household activity prior to ca. $170 \mathrm{BC}$ and only after that did professional bakers appear in the city, to which might be added the claim made by other Roman writers that their predecessors subsisted on emmer porridge, while bread was an impressive but morally-problematic part of the new food obsessions of the last couple of centuries BC (Purcell 2003).

As both the volume of grain trade and the demand for bread increased, so too did the need for cereal species that were both faster from-field-to-food and particularly breadenabling ('panifiable'). Several shifts in the relative frequency of different cereal species over the latter half of the 1st millennium BC are worth emphasising. First, there appears to be increasing priority placed on durum wheat (Triticum durum) in key regions such as Ptolemaic and Roman Egypt in the 2nd to 1st centuries BC (where the earlier tradition was of emmer and barley: Mayerson 2002; Murray 2000), and this species was also dominant in Tunisia and Sicily, probably reflecting its importance in supplying the city of Rome by ship. Elsewhere, in both the Mediterranean and further north, bread wheat (Triticum aestivum), perhaps most suited to slightly wetter climates (e.g. southern Russia, the northern Balkans, northern Italy, Gaul and Britain: Garnsey 1999: 120), also seems to increase in popularity without ever supplanting all the alternatives (e.g. Zech-Matterne, Wiethold and Pradat 2014). Clean grains of free-threshing durum and bread wheat could be obtained without the dehusking (extra pounding-and-sieving steps) otherwise needed for barley or glume wheats such as emmer and einkorn. So despite the fact that they were certainly not new species, durum and bread wheats were 
increasingly found to be well-adapted to a market economy, for example to larger elite estates that produced routinely-refreshed grain pools stored in carefully-monitored above-ground granaries with a view to private, state-organised or military flour-andbread supply chains.

A final shift in the cereal types of temperate Europe (from the Alps northwards and also the Atlantic fringe, but not further south), was towards increased proportions of spelt wheat (Triticum spelta, see Mills 2006; Sigaut 1989). Spelt possessed a particularly protective glume that made it well-adapted to high humidity and cold in Europe's mid-latitudes, at the same time as providing grains that were glutinous enough to produce a bread. Even so, the storage logic for spelt was quite different from durum and bread wheats and better-suited to more northerly climates, with whole spelt ears often stored together for processing in small batches over the winter (as was probably the case for other glume wheats in these regions). The post-granaries, that become such a feature of Iron Age temperate Europe in some places, were multipurpose but probably have particular links to this species (Sigaut 1989). In any case, such changes accentuated a pre-existing northsouth difference. Mediterranean grains were typically threshed immediately after harvest, and the increase in free-threshing varieties meant that even more of the necessary human labour was thereby 'front-loaded' (see Bettinger 2015: 90-91) so that effort went in early to create a cleaner stored product. In contrast in northern Europe, cereals were often stored unthreshed in ears (in later periods, also with full stalks as sheaves) and there was often a preference for cereals that also required further dehusking (spelt, emmer, einkorn, barley), so the northern grain store was thus on average a less finished, less immediately commodifiable form of capital. That said, within both the Mediterranean and temperate Europe in the 1st millennium BC, certain places were able to mobilise labour and created more processed cereals than others which probably maps on to local political complexity and social inequality (Fuller and Stevens 2012; Van der Veen and Jones 2006).

\section{Leveraging liquids}

Three interesting forms of 'liquidity' have underwritten Mediterranean economic and social life since at least the Bronze Age, and they all become a basin-wide phenomena for the first time in the 1st millennium BC. The first is in a sense the most obvious, the connectivity enabled by the Mediterranean sea itself, along a mid-latitude Eurasian ecotone that already encouraged east-west flow of goods, people and ideas. This enabling role for the Mediterranean Sea becomes turbocharged once sailing ships are a feature of the entire basin during the 1st millennium BC. A second kind of liquidity involved the commonplace use of recyclable metals, and the apical role they played in almost all hierarchies of Mediterranean and European material culture, with bullion flows of ingots, finished objects, scrap metal and/or coins at different times, all within a clearly graded value hierarchy (Bevan 2010: 48-57), and with coinage a particularly unifying new component in the later 1st millennium. Metals may not have direct connections to the enhanced role of preserved and stored foods, but they were key to the high levels of commercial transaction that meant foodkeeping was not just important for survival, but also very profitable as convertible value. A third crucial form of liquidity and the most relevant here, came in the form of highly-processed, vertically-differentiated, fluid commodities such as oils and wines. These quintessentially Mediterranean products allowed grapes and olives to be kept for longer (wine for potentially many years) but required investments in new kinds of landscape (vineyards and groves), new dining or ablutionary practices, new kinds of highly specialised storage, processing and transport containers (of which more below) and elaborate, new marking practices (e.g. seals, inscriptions, decoration; Bevan 2010, 2014).

The contrast to beer is instructive. Beer was also a liquid becoming far more prominent 
in the second half of the 1st millennium BC, with archaeobotanical evidence for deliberate grain malting (Styring et al. 2017), documentary mention of Celtic brewing traditions and the first archaeological finds of barrels (Marlière 2002). One of the reasons for more elaborate Iron Age grain storage structures and pooling of harvests may then have been an uptick in beer-making and the politically and socially-significant feasting this practice enabled. However, beer stores far less well than wine, and typically requires greater concentrations of human labour to create large batches. So beer was well-suited to a largescale feasting at or near sites of centralised cereal storage (e.g. the hillforts of temperate Europe), and less attractive for long-distance trade and stock-piling (Jennings et al. 2005).

By the 2nd millennium BC there was already a vibrant commercial trade in oils (albeit at least at this stage often as perfumes rather than food) and wines across the eastern Mediterranean (for the preceding history, see Broodbank 2013; Lentjes and Saltini Semerari 2016; Langgut et al. 2019; Pérez-Jordà et al. 2017), but significant investment in wine and olive oil as a commodity only begins in southern Italy in the very late Bronze Age or early Iron Age, and later still in southern France and Iberia as a consequence of Phoenician and Greek colonisation. Wine and oil were distinctive added value products that further fostered the development of two specialised storage and transport containers: the amphora and the pithos. The historical geography of these vessels (when and where they developed and spread) closely tracks the historical geography of wine and oil production. By the 2nd millennium BC several distinctive amphora-like vessels were regular trade containers around the eastern Mediterranean, and pithoi had become commonplace features of economic life, from small farmsteads up to large palace magazines. Even so, the embracing of these container traditions across the entire Mediterranean basin was very much a feature of the 1 st millennium BC.
Amphoras were usually wheel-made, often with pointed-bases that made them less vulnerable to breakage and, along with their handles, provided reliable points-ofpurchase with which to handle them. They were the right size, weight and shape to be stacked in the holds of ships, placed in racks, slung on ropes, leaned against one another, half-buried in the ground or hoisted on the shoulders of human porters. Their narrow necks could be closed with a stopper and sealed with lime or clay (Bevan 2014; Grace 1949: 175). The bigger terrestrial cousins of such amphoras were, in turn, enormous clay storage jars (aka Roman dolia or Greek pithoi, Figure 2a, c; Bevan 2018). Again, there is an earlier history across both temperate Europe and the Mediterranean of experimenting with larger clay vessels, but systematic efforts to produce lots of them in increasing sizes (e.g. more than half a metre in height and from 100L to as much as 2000L capacity) required potting specialisation and often more elaborate kiln architecture, and as a result the appearance of out-sized clay storage jars often constitutes a distinct chronological horizon (sometimes also visible in local funerary practice as a 'pithos-burials') in different regions at different times. Such jars could be set deep into the ground or left free-standing, and were a sealable, fairly vermin-resistant way to store goods at a reasonably stable temperature. They were often closely linked to wine production, but also commonly used for storing olive oil, cereals and other products (Bevan 2018).

Both of these newly-ubiquitous clay creatures come to play very important roles in Mediterranean thought and culture during the Iron Age and Roman periods, but here I would just like to stress one slightly underacknowledged, more quantitative feature of them as a form of evidence: they make very useful macro-economic proxies. For example, several researchers have noted that different Mediterranean amphora types get taller in shape over the course of the 1st millennium $\mathrm{BC}$, often without major accompanying changes in capacity. Even just calculating a 


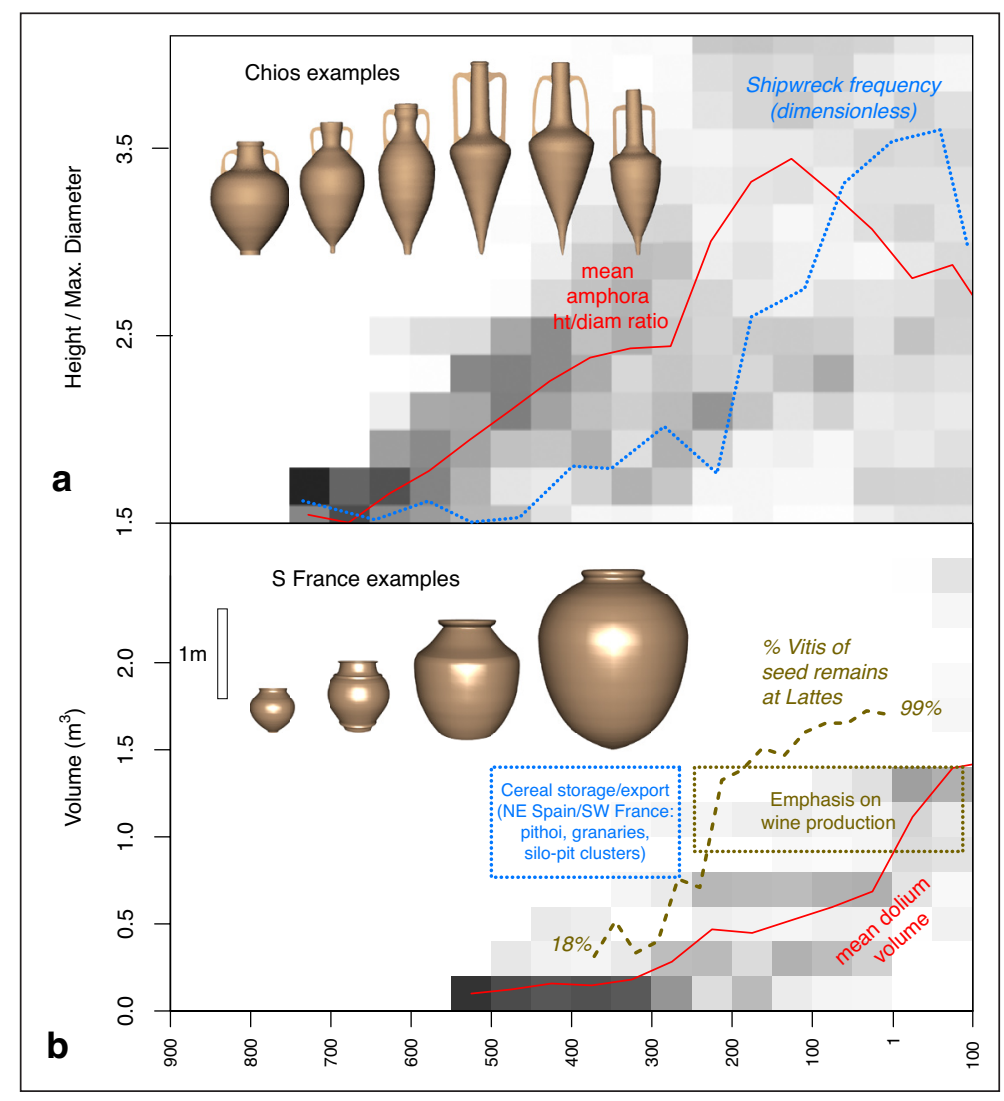

Figure 2: Storage dynamics through Iron Age containers (Figure: A. Bevan): (a) a bivariate histogram and weighted mean of amphora height-width ratios $(n=688$ types, see Bevan 2014 for source data), along with the frequency of Mediterranean shipwrecks (after Wilson 2009, fig. 9.4) and (b) a bivariate histogram of large storage jar (dolium) volumes from southern France ( $\mathrm{n}=32$ types, solid-of-revolution profiles from drawings in Marlier and Sciallano 2008; Py 1993), along with the changing percentage of grape seeds amongst all seeds from the major port site of Lattes (after Py and Buxó 2001: fig. 4).

simple ratio of height to diameter, and plotting the results for several hundred amphora types, produces clear trend towards steadily taller shapes (Figure 2a). This can be juxtaposed with other possible indicators for long-term, macroeconomic activity, such as the number of observed Mediterranean shipwrecks, to explore what appears to be a real peak of activity reached by the 1st century BC. Taller amphoras suggest a changing niche, in which: (a) amphora potters were increasingly skilled in turning out difficult shapes, (b) a focus on wine production encouraged thin, anti-oxidant designs with less exposure of the contents to leakage or trapped air near the opening and/or (c) deeper, larger ship holds favouring taller amphoras that were more space-efficient and less vulnerable in stacks (Bevan 2014: 403-404).

Similarly, storage jars show real promise as time series data. For example, from the start of the 6th century BC onwards, new colonies such as Marseilles had a profound effect on local economic and cultural life in Languedoc, Roussillon and northern Catalonia. One sign of this is a striking mix of cereal storage solutions (storage jars, silo pit concentrations, Celtic-style post-granaries 
and other Greek and/or Punic above-ground stores: Garcia 1997: 91-94; Van Oyen 2019). Amongst these, the storage jar starts being made locally quite early on (Olive et al. 2009) and while it may initially have had a greater role in cereal-storing (probably for export), greater emphasis thereafter seems to have been placed on its use for wine production and trade. Figure $\mathbf{2} \mathbf{b}$ suggests a steady increase in the average capacity of southern French storage jars, but one that seems delayed in comparison to amphora trends, shipwreck statistics or indeed local archaeobotanical observations of grape-seed prevalence, suggesting the these larger vessels responded more slowly to wider macro-economic changes (for excellent discussions of possible links to changing demography, see also Garcia and Isoardi 2010; Sacchetti and Isoardi 2017).

\section{Concluding Remarks}

The above exploration has briefly tried to capture a compelling moment in the food strategies of Europe and the Mediterranean. The 1st millennium $\mathrm{BC}$ is perhaps the first period where we can speak of a coherent north-south divide between pithos-amphora-olive-andvine economies in the Mediterranean and quite different barrel-beer-butter economies further north, albeit with important connections and overlaps between them. Salted and otherwise preserved meats and fish become increasingly industrialised as products. Bread gradually gains ground over porridges and other grain-consumption traditions, albeit to different degrees in different places, with interesting consequences for what cereal species were preferred and how they were stored. Overall, the evidence provides a nice vantage on the emergence of both ends of a food-security spectrum (a feature not lost on ancient writers and still obsessing modern planners today): simply, whether (a) to store up diverse provisions locally in hoards or (b) to rely on the financialisation of food and general market velocity to mitigate similar resource risks. A further remarkable feature is the relationship between food storage and urbanisation, with demographic concentration co-evolving with the concentration of trade routes, of concentrated storage spaces, of store-adapted insects and indeed often of mono-crops. Beyond this, the discussion above has hardly touched on certain key topics, such as the relationship between storage, property rights, social inequalities or gender roles (Earle 2017; Kanafani-Zahar 1994), but even so, it has hopefully emphasised the potential offered by a comparative approach to these key features of human subsistence and social life.

\section{Acknowledgements}

This paper arises from an ongoing, booklength piece of research on European food storage that I started working on during sabbatical leave. Many thanks to colleagues who enabled that time away and have since offered input. Thanks also to the organisers and participants of an inspiring 2016 workshop (Radcliffe Institute, Boston) about how containers and storage might fit into human social life (see Shryock and Smail eds. 2018). Further and final gratitude to Todd Whitelaw and Greg Woolf for kindly reading early drafts, to Barry Cunliffe, Ian Cartwright and Serena Sabatini for useful image permissions, and to two anonymous reviewers.

\section{Competing Interests}

The author has no competing interests to declare.

\section{References}

Ailincăi, C S 2015 Living with the dead. Burials in Early Iron Age settlement at Enisala-Palanca, Tulcea county (SouthEastern Romania). Sprawozdania Archeologiczne, 67: 221-241.

Alston, R and van Nijf, O (eds.) 2008 Feeding the Ancient Greek City. Leuven: Peeters.

Arnoldussen, S 2008 A Living Landscape: Bronze Age settlement sites in the Dutch river area (c. 2000-800 BC). Leiden: Sidestone. http://hdl.handle. net $/ 1887 / 13070$

Balbo, A L (ed.) 2015 Storage (Environmental Archaeology 20.4 - Special Issue). DOI: 
https://doi.org/10.1179/17496314 15Y.0000000021

Bettinger, R L 2015 Orderly Anarchy. Socio-political Evolution in Aboriginal California. Los Angeles: University of California Press.

Bevan, A 2010 Making and marking relationships: Bronze Age brandings and Mediterranean commodities. In: Bevan, A and Wengrow, D (eds.) Cultures of Commodity Branding. Walnut Creek: Left Coast Press. pp. 35-86. DOI: https://doi. org/10.4324/9781315430898

Bevan, A 2014 Mediterranean containerization. Current Anthropology, 55(4): 387-418. DOI: https://doi. org/10.1086/677034

Bevan, A 2018 Pandora's pithos. History and Anthropology, 29(1): 7-14. DOI: https:// doi.org/10.1080/02757206.2017.1397651

Biederer, B 2018 Verteilungsmuster spätbronzezeitlicher Speichergruben in Mitteleuropa. Archaeologia Austriaca, 102: 169-199. DOI: https://doi. org/10.1553/archaeologia102s169

Bogaard, A (ed.) 2017 The Archaeology of Food Surplus (World Archaeology 49.1 Special Issue). DOI: https://doi.org/10.10 80/00438243.2017.1294105

Bossard, S 2019 Évolution du stockage agricole dans la moitié septentrionale de la France à. l'âge du Fer (VIe-Ier s. av. n. è.). In: Martin, S (ed.) Rural Granaries in Northern Gaul (6th Century BCE-4th Century CE). From Archaeology to Economic History. Leiden: Brill. pp. 51-72. DOI: https://doi. org/10.1163/9789004389045_006

Bradley, R 2002 Death and the regeneration of life: a new interpretation of house urns in northern Europe. Antiquity, 76: 372-377. DOI: https://doi.org/10.1017/ S0003598X00090463

Brigand, R and Weller, 0 (eds.) 2015 Archaeology of Salt: Approaching an Invisible Past. Leiden: Sidestone Press.

Broodbank, C 2013 The Making of the Middle Sea: A History of the Mediterranean from the Beginning to the Emergence of the Classical World. London: Thames and Hudson

Buchsenschutz, 0 (ed.) 2015 L'Europe Celtique à l'Âge du Fer (VIII $-I^{\text {er }}$ siècles). Paris: Presses Universitaire de France.

Carrer, F, Colonese, A C, Lucquin, A, Petersen Guedes, E, Thompson, A, Walsh, K et al. 2016 Chemical analysis of pottery demonstrates prehistoric origin for high-altitude Alpine dairying. PLOS ONE, 11(4): e0151442. DOI: https://doi. org/10.1371/journal.pone.0151442

Carusi, C 2008 Il Sale nel Mondo Greco (VI a.C.-III d.C.). Luoghi di Produzione, Circolazione Commerciale, Regimi di Sfruttamento nel Contesto del Mediterraneo Antico, Bari: Edipuglia.

Casson, L 1954 The grain trade of the Hellenistic world. Transactions and Proceedings of the American Philological Association, 85: 168-187. DOI: https:// doi.org/10.2307/283474

Chapman, J and Gaydarska, B 2003 The provision of salt to Tripolye mega-sites. In: Korvin-Piotrovskiy, O G (ed.) Tripil'ski Poselennya-Giganti: Materiali Mizhnarodnoy Konferentsiy. Korvin. pp. 203-211.

Columella 1954 Res Rustica/On Agriculture (Volume II: Books 5-9). Translated by Forster, E S and Heffner, E H. Cambridge, MA: Harvard University Press (Loeb Classical Library 407).

Cronin, T, Downey, L, Synnott, C, McSweeney, P, Kelly, E P, Cahill, M, Ross, R P and Stanton, C 2007 Composition of ancient Irish bog butter. International Dairy Journal, 17(9): 10111020. DOI: https://doi.org/10.1016/j. idairyj.2007.01.012

Cunliffe, B 1992 Pits, preconceptions and propitiation in the British Iron Age. Oxford Journal of Archaeology, 11(1): 69-83. DOI: https:// doi.org/10.1111/j.1468-0092.1992. tb00257.x

Curtis, R I 1991 Garum and Salsamenta: Production and Commerce in Materia Medica. Leiden: Brill. DOI: https://doi. org/10.1163/9789004377264_005 
Daire, M-Y 2003 Le Sel des Gaulois. Paris: Errance.

Deffressigne, S, Landolt, $M$ and Gransar, F 2017 L'évolution du stockage entre le XIe et le IIIe siècle a.C. dans les vallées de la Moselle, de la Meurthe et du Rhin. In: Marion, S, Deffressigne, S, Kaurin, $\mathrm{J}$ and Bataille, G (eds.) Production et Proto-Industrialisation aux Âges du Fer: Perspectives Sociales et Environnementales. Nancy: Ausonius. pp. 77-100.

Delattre, V and Auxiette, G 2018 Homme vs animal: une même intention cultuelle dans les dépôts domestiques du second Âge du Fer dans le Bassin Parisien? In: Costamagno, $\mathrm{S}$ et al. (eds.) Animal Symbolisé, Animal Exploité: du Paléolithique à la Protohistoire. Paris: Éditions du Comité des Travaux Historiques et Scientifiques. pp. 329-345. DOI: https://doi. org/10.4000/books.cths.4697

Delattre, V, Bulard, A, Gouge, $\mathbf{P}$ and Pihuit, P 2000 De la relégation sociale à l'hypothèse des offrandes: l'exemple des dépôts en silos protohistoriques au confluent Seine-Yonne (Seine-etMarne). Revue Archéologique du Centre de la France, 39 : 5-30. DOI: https://doi. org/10.3406/racf.2000.2843

Earle, T 2017 Property in prehistory. In: Graziadei, $\mathrm{M}$ and Smith, $\mathrm{L}$ (eds.) Comparative Property Law: Global Perspectives. Northampton: Elgar. pp. 3-25. DOI: https://doi. org/10.4337/9781785369162.00008

Evershed, R P, Payne, S, Sherratt, A G, Copley, M S, Coolidge, J et al. 2008 Earliest date for milk use in the Near East and southeastern Europe linked to cattle herding. Nature, 455: 528-531. DOI: https://doi.org/10.1038/nature07180

Fernández-Götz, M 2018 Urbanization in Iron Age Europe: trajectories, patterns, and social dynamics. Journal of Archaeological Research, 26: 117-162. DOI: https://doi.org/10.1007/s 10814-0179107-1

Fernández-Götz, M and Krausse, D (eds.) 2016 Eurasia at the Dawn of History:
Urbanization and Social Change. New York: Cambridge University Press. DOI: https:// doi.org/10.1017/9781316550328

Fuller, D Q and Stevens, C J 2012 Agriculture and the development of complex societies: An archaeobotanical agenda. In: Fairbairn, A S and Weiss, E (eds.) From Foragers to Farmers. Gordon C. Hillman Festschrift. Oxford: Oxbow. pp. 37-57.

Fuller, D Q and Stevens, C J 2017 Open for competition: domesticates, parasitic domesticoids and the agricultural niche. Archaeology International, 20: 110-121. DOI: https://doi.org/10.5334/ai.359

García, D 1997 Les structures de conservation des céréales en Méditerranée nord-occidentale au premier millénaire avant J.-C.: Innovations techniques et rôle économique. In: Meeks, D and García, D (eds.) Techniques et Économie Antiques et Médiévales: Le Temps de l'Innovation. Aix-en-Provence: Errance. pp. 88-95.

García, D and Isoardi, D 2010 Variations démographiques et production des céréales en Celtique méditerranéenne: le rôle de Marseille grecque? In: Tréziny, H (ed.) Grecs et Indigènes de la Catalogne à la Mer Noire. Aix-en-Provence: Centre Camille Jullian. pp. 403-424.

Garnsey, P 1988 Famine and Food Supply in the Graeco-Roman World. Responses to Risk and Crisis. Cambridge: Cambridge University Press. DOI: https://doi. org/10.1017/CBO9780511583827

Garnsey, P 1999 Food and Society in Classical Antiquity. Cambridge: Cambridge University Press. DOI: https://doi. org/10.1017/CBO9780511612534

Gast, $\mathbf{M}$ and Sigaut, F (eds.) 1979 Les Techniques de Conservation des Grains I. Leur Rôle dans la Dynamique des Systèmes de Cultures et des Sociétés. Paris: CNRS.

Gent, H 1983 Centralized storage in later prehistoric Britain. Proceedings of the Prehistoric Society, 49: 243267. DOI: https://doi.org/10.1017/ S0079497X00008008

Giguet-Covex, C et al. 2014 Long livestock farming history and human landscape 
shaping revealed by lake sediment DNA. Nature Communications, 5: 3211. DOI: https://doi.org/10.1038/ncomms4211

Grace, V 1949 Standard pottery containers of the ancient Greek world. Hesperia Supplements 8 (Commemorative Studies in Honor of Theodore Leslie Shear): 175-189. DOI: https://doi. org/10.2307/1353892

Grainger, S 2018 Garum and Liquamen. What's in a Name? Journal of Maritime Archaeology, 13(3): 247-261. DOI: https://doi.org/10.1007/s11457-0189211-5

Gransar, F 2000 Le stockage alimentaire sur les établissements ruraux de l' Âge du Fer en France septentrionale: complémentarité des structures et tendances évolutives. In: Marion, S and Blancquaert, $\mathrm{G}$ (eds.) Les Installations Agricoles de l'âge du Fer en France Septentrionale. Paris: Éditions Rue d'Ulm. pp. 277-298.

Gransar, F 2003 L'apport de l'étude du stockage à la reconstruction des systèmes agro-alimentaire de l' l' Âge du Fer en France septentrionale. In: Anderson, P C (ed.) Le Traitement des Récoltes:Un Regard sur la Diversité du Néolithique au Présent. Antibes: Editions APDCA. pp. 201-218.

Griebl, M, Biederer, B, Jachs, $\mathbf{T}$ and Petschko, I 2017 Aktuelle Forschungen zu den Speichergruben auf der Späturnenfelderzeitlichen Wallanlage von Stillfried an der March. In: Pieler, F and Trebsche, P (eds.) Beiträge zum Tag der Niederösterreichischen Landesarchäologie 2017. Festschrift für Ernst Lauermann. St. Pölten: Eigenverlag. pp. 195-205.

Groenewoudt, B J 2015 The visibility of storage. In: Klápšte, J and Sommer, P (ed.) Food in the Medieval Rural Environment: Processing, Storage, Distribution of Food. Turnhout: Brepols (Ruralia 8). pp. 187198. DOI: https://doi.org/10.1484/M. RURALIA-EB.1.100165

Harding, A 2013 Salt in Prehistoric Europe. Leiden: Sidestone Press.

Haselgrove, C 2007 The age of enclosure: later Iron Age settlement and society in northern France. In: Haselgrove,
$\mathrm{C}$ and Moore, $\mathrm{T}$ (eds.) The Later Iron Age in Britain and Beyond. Oxford: Oxbow. pp. 492-522. DOI: https://doi. org/10.2307/j.ctvh1dsh9.32

Holzer, V and Stadler, P 2008 Ein latènezeitlicher Getreidespeicher aus der keltischen Großsiedlung am Sandberg in Roseldorf (Niederösterreich). Germania, 86: 135-179.

Homer 1924 Iliad (Volume I: Books 1-12). Translated by Murray, A T Revised by Wyatt, W F. Cambridge, MA: Harvard University Press (Loeb Classical Library 170). DOI: https://doi.org/10.4159/ DLCL.homer-iliad.1924

Itan, Y, Powell, A, Beaumont, M A, Burger, J, Thomas, M G 2009 The origins of lactase persistence in Europe. PLoS Computational Biology, 5(8): e1000491. DOI: https://doi.org/10.1371/journal. pcbi.1000491

Jennings, J, Antrobus, $\mathrm{K} \mathrm{L}$, Atencio, S J, Glavich, E, Johnson, R, Loffler, G and Luu, C 2005 "Drinking beer in a blissful mood". Alcohol production, operational chains, and feasting in the Ancient World. Current Anthropology, 46(2): 275-303. DOI: https://doi.org/10.1086/427119

Jeunnesse, C 2010 Les sépultures en fosses circulaires de l'horizon 4500-3500: contribution à l'étude comparée des systèmes funéraires du Néolithique européen. In: Boulestin, B and Baray, L (eds.) Morts Anormaux et Sépultures Bizarres. Les Dépôts Humains en Fosses Circulaires ou en Silos du Néolithique à l' Âge du Fer. Dijon: Editions Universitaires de Dijon. pp. 37-56.

Kanafani-Zahar, A 1994 Mūne. La Conservation Alimentaire Traditionnelle au Liban. Paris: Maison des Sciences de l'Homme.

Kinory, J L 2012 Salt Production, Distribution and Use in the British Iron Age. Oxford: Archaeopress.

Király, A, Sebők, K, Zoffmann, Z K and Kovács, G 2013 Early Iron Age 'mass graves' in the Middle Tisza region: investigation and interpretation. In: MüllerScheeßel, N (ed.) Irreguläre Bestattun- 
gen in der Urgeschichte: Norm, Ritual, Strafe...? Bonn: German Archaeological Institute/Rudolf Habelt. pp. 307-326.

Kunz, L 2004 Obilní Jámy: Konzervace Obilí na Dlouhý Čas v Historické Zóně Eurosibiřského a Mediteránního Rolnictví, Rožnov pod Radhoštěm, Rožnov pod Radhoštěm. Wallachian Open Air Museum.

Landolt, M, Millet, É, Roth-Zehner, M, Barrand, H, Cartier, E, Mauduit, A and Putelat, 02010 Pratiques funéraires en Alsace du Ve au Ier siècle avant J.-C. In: Barral, P, Dedet, B, Delrieu, F, Giraud, P, Le Goff, I, Marion, S and Villard-Le Tiec, A (eds.) L'Âge du Fer en Basse Normandie: Gestes Funéraires en Gaule au Second Âge du Fer. Besançon: Presses Universitaire de Franche-Comté. pp. 207-230.

Langgut, D, Cheddadi, R, Sebastián Carrión, J et al. 2019The origin and spread of olive cultivation in the Mediterranean Basin: The fossil pollen evidence. The Holocene, 29(5): 902-922. DOI: https://doi. org/10.1177/0959683619826654

Lentjes, D and Semerari, G S 2016 Big debates over small fruits. Wine and oil production in protohistoric southern Italy (ca 1350-750 BC). BABESCH, 91: 1-16. DOI: https://doi.org/10.2143/ BAB.91.0.3175640

Le Brun Ricalens, F 2014 Du rite au mythe ? Essai d'interprétation de certains silos funéraires protohistoriques d'Europe nord-occidentale à partir des fouilles de Remerschen (G.-D. de Luxembourg). Archaeologia Mosellana, 9: 153-208.

Maltby, M 2006 Salt and animal products: linking production and use in Iron Age Britain. In: Maltby, $M$ (ed.) Integrating Zooarchaeology. Oxford: Oxbow. pp. 117122.

Manzanilla, L R and Rothman, M S (eds.) 2016 Storage in Ancient Complex Societies. Administration, Organization and Control. New York and London: Routledge.

Marlière, E 2002 L'Outre et le Tonneau dans l'Occident Romain. Montagnac: Monographies Instrumentum.
Martin, S (ed.) 2019 Rural Granaries in Northern Gaul (6th Century BCE-4th Century (E). From Archaeology to Economic History. Leiden: Brill. DOI: https://doi. org/10.1163/9789004389045

Mattingly, D and Aldrete, G S 2000 The feeding of imperial Rome: the mechanics of the food supply system. In: Coulston, $\mathrm{J}$ and Dodge, $\mathrm{H}$ (eds.) Ancient Rome. Oxford: Oxford University School of Archaeology. pp. 142-165. DOI: https:// doi.org/10.2307/j.ctvh1dk0c.11

Mayerson, P 2002 Three Pharaonic crops

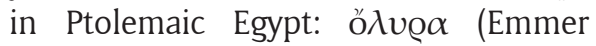

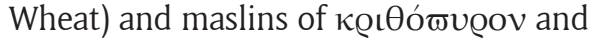

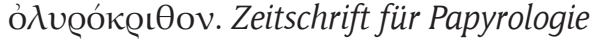
und Epigraphik, 141: 210-213.

Mills, T 2006 A Study of European Cereal Frequency Change during the Iron Age and Roman Periods. Unpublished thesis (PhD), University of Sheffield.

Moreno, A 2007 Feeding the Democracy. The Athenian Grain Supply in the Fifth and Fourth Centuries BC. Oxford: Oxford University Press.

Morère, N 2013 Les problématiques du sel dans l'Hispanie préromaine et romaine. Folia Electronica Classica, 26.

Morales-Muñiz, A and Roselló Izquierdo, E 2008 Twenty thousand years of fishing in the Strait. Archaeological fish and shellfish assemblages from southern Iberia. In: Rick, $\mathrm{T} \mathrm{C}$ and Erlandson, $\mathrm{J}$ (eds.) Human Impacts on Ancient Marine Ecosystems: A Global Perspective. Berkeley: University of California Press. pp. 243-278.

Murray, M-A 2000 Cereal production and processing. In: Nicholson, P.T. and I. Shaw (eds.) Ancient Egyptian Materials and Technology. Cambridge: Cambridge University Press. pp. 505-536

Olive, C, Ugolini, D, Ratsimba, A, Jandot, C and Wiégant, J-P 2009 Un four de potier de l'âge du Fer pour la cuisson de pithoi à Béziers (Hérault): production, diffusion et fonction du pithos dans le Midi (VI e -IV e s. av. J.-C.). Gallia, 66(2): 29-57. DOI: https://doi.org/10.3406/ galia.2009.3366 
Panagiotakopoulu, E and Buckland, P C 2017 A thousand bites. Insect introductions and late Holocene environments. Quaternary Science Reviews, 156: 23-35. DOI: https://doi.org/10.1016/j.quascirev.2016.11.014

Pearce, M 2016 Hard cheese: Upland pastoralism in the Italian Bronze and Iron Ages. In: Collis, J, Pearce, $\mathrm{M}$ and Nicolis, F (eds.) Summer Farms. Seasonal Exploitation of the Uplands from Prehistory to the Present. Sheffield: Collis. pp. 47-56.

Péfau, P 2017 Pan de bois et contreventement oblique en Gaule à l'âge du Fer. Gallia, 74(2): 19-41. DOI: https://doi. org/10.4000/gallia.2063

Peña-Chocarro, L, Pérez Jordà, G, Morales Mateos, J and Zapata, L 2015 Storage in traditional farming communities of the western Mediterranean: Ethnographic, historical and archaeological data. Environmental Archaeology, 20(4): 379-389. DOI: https://doi.org/10.1179/17496314 15Y.0000000004

Pérez-Jordà, G, Peña-Chocarro, L, García Fernández, $\mathrm{M}$ and Carlos Vera Rodríguez, J 2017 The beginnings of fruit tree cultivation in the Iberian Peninsula: plant remains from the city of Huelva (southern Spain). Vegetation History and Archaeobotany, 26:527-538. DOI: https:// doi.org/10.1007/s00334-017-0610-6

Pliny 1940 Historia Naturalis/Natural History (Volume III: Books 8-11). Translated by Rackham, H. Cambridge, MA: Harvard University Press (Loeb Classical Library 353).

Pliny 1950 Historia Naturalis/Natural History (Volume V: Books 17-19). Translated by Rackham, H. Cambridge, MA: Harvard University Press (Loeb Classical Library 371).

Purcell, N 2003 The way we used to eat. Diet, community, and history at Rome. American Journal of Philology, 124(3): 329358. DOI: https://doi.org/10.1353/ ajp.2003.0051

Py, M 1993 DICOCER. Dictionnaire des Céramiques Antiques(VIIème s.av.n.è. - VIIème s. de n.è.) en Méditerranée Nord-Occidentale (Provence, Languedoc, Ampurdan). Lattes: Edition de l'Association pour la Recherche Archéologique en Languedoc Oriental.

Py, M and Buxó, R 2001 La viticulture en Gaule à l'Âge du Fer: La viticulture en Gaule. Gallia, 58(1): 29-43. DOI: https:// doi.org/10.3406/galia.2001.3172

Rickman, G E 1980 The Corn Supply of Ancient Rome. Cambridge: Cambridge University Press.

Ridgway, D 1997 Nestor's cup and the Etruscans. Oxford Journal of Archaeology, 16(3): 325-344. DOI: https://doi. org/10.1111/1468-0092.00044

Rzeźnicka, Z, Kokoszko, M and Jagusiak, K 2014 Cured meats in Ancient and Byzantine sources: ham, bacon and tuccetum. Studia Ceranea, 4: 245-259. DOI: https://doi.org/10.18778/2084140X.04.16

Sabatini, S 2007 House Urns. A European Late Bronze Age Trans-cultural Phenomenon. Gothenburg: University of Gothenburg.

Sacchetti, F and Isoardi, D 2017 Production et consommation au premier âge du Fer : vers une modélisation des impacts socioéconomiques des contact entre le sud-est de la France et l'Europe centre-occidentale (Vie-Ve s. a.C.). In: Marion, S, Deffressigne, S, Kaurin, J and Bataille, G (eds.) Production et Proto-Industrialisation aux Âges $d u$ Fer. Nancy: AFEAF. pp. 621-648.

Salque, M, Bogucki, P I, Pyzel, J, Sobkowiak-Tabaka, I, Grygiel, R, Szmyt, M and Evershed, R P 2013 Earliest evidence for cheese making in the sixth millennium $\mathrm{BC}$ in northern Europe. Nature, 493(7433): 522-525. DOI: https://doi.org/10.1038/nature11698

Sciallano, M and Marlier, S 2008 L'épave à dolia de l'île de la Giraglia (Haute Corse). Archaeonautica, 15: 113-151. DOI: https://doi.org/10.3406/nauti.2008.919

Sherratt, A 1981 Plough and pastoralism: Aspects of the secondary products revolution. In: Hodder, I Isaac, G and 
Hammond, N (eds.) Pattern of the Past. Cambridge: Cambridge University Press. pp. 261-306.

Shryock, A and Smail, D L (eds.) 2018 On Containers: A Forum (History and Anthropology 29.1 - Special Issue). DOI: https:// doi.org/10.1080/02757206.2017.1397650

Sigaut, F 1989 Les spécificités de l'épeautre et l'évolution des techniques. In: Devroey, J-P. and J-J. Van Mol (eds.) L'Épeautre, Histoire et Ethnologie. Treignes: Université Libre de Bruxelles. pp. 29-49.

Smyth, J, Berstan, R, Casanova, E et al. 2019 Four millennia of dairy surplus and deposition revealed through compound-specific stable isotope analysis and radiocarbon dating of Irish bog butters. Scientific Reports, 9(4559). DOI: https:// doi.org/10.1038/s41598-019-40975-y

Stroud, R S 1998 The Athenian Grain-Tax Law of 374/3 B.C. Princeton: Hesperia Supplements 29. DOI: https://doi. org/10.2307/1354031

Styring, A, Rösch, M, Stephan, E, Stika, H-P, Fischer, E, Sillmann, $\mathbf{M}$ and Bogaard, A 2017 Centralisation and long-term change in farming regimes: Comparing agricultural practices in Neolithic and Iron Age south-west Germany. Proceedings of the Prehistoric Society, 83: 357-381. DOI: https://doi.org/10.1017/ ppr.2017.3

Thurmond, D L 2006 A Handbook of Food Processing in the Classical Rome. Leiden: Brill.

Unger, J and Pecinovská, M 2015 Obříství, a Late Bronze Age port of trade in central Bohemia. Studia Hercynia, 29(1-2): 71-95. http://hdl.handle. net/20.500.11956/97168

Van De Noort, R, Chapman, $\mathbf{H}$ and Collis, J 2007 Sutton Common. The Excavation of an Iron Age 'Marsh-fort'. York: Council for British Archaeology.

Van der Veen, $\mathbf{M}$ and Jones, G 2006 A reanalysis of agricultural production and consumption: implications for understanding the British Iron Age. Vegetation History and Archaeobotany, 15: 217-228.
DOI: https://doi.org/10.1007/s00334 006-0040-3

Van Oyen, A 2015 The moral architecture of villa storage in Italy in the 1st century BC. Journal of Roman Archaeology, 28(1): 97-123. DOI: https://doi.org/10.1017/ S1047759415002421

Van Oyen, A 2019 Rural time. World Archaeology. DOI: https://doi.org/10.1080/004 38243.2019.1601461

Walthall, A 2015 Recenti scavi nei granai monumentali di Morgantina, In: Maniscalco, L (ed.) Morgantina Duemilaequindici. La Ricerca Archeologica a Sessant'anni dall'avvio degli Scavi. Palermo: Dipartimento dei Beni Culturali e dell 'identità Siciliana. pp. 82-91.

Wilson, A G 2009 Approaches to quantifying Roman trade. In: Bowman, A and Wilson, A G (eds.) Quantifying the Roman Economy: Methods and Problems. Oxford: Oxford University Press. pp. 213-249. DOI: https://doi.org/10.1093/acprof: oso/9780199562596.003.0009

Woolf, G 1990 Food, poverty and patronage: The significance of the epigraphy of the Roman alimentary schemes in Early Imperial Italy. Papers of the British School at Rome, 58: 197-228. DOI: https://doi. org/10.1017/S006824620001165X

Zech-Matterne, V, Malrain, F and Auxiette, G 2013 Essai d'approche des systèmes agricoles laténiens dans le Nord-Ouest de la France: données carpologiques archéozoologiques et archéologiques. In: Krausz, S, Colin, A, Gruel, K, Ralston, I and Dechezleprêtre, T (eds.) L'Âge $d u$ Fer en Europe. Mélanges Offerts à Olivier Buchsenschutz. Bordeaux: Ausonius. pp. 381-388.

Zech-Matterne, V, Wiethold, J and Pradat, B 2014 L'essor des blés nus en France septentrionale: systèmes de culture et commerce céréalier autour de la conquête césarienne et dans les siècles qui suivent. In: Deru, $\mathrm{X}$ and González Villaescusa, $\mathrm{R}$ (eds.) Consommer dans les Campagnes de la Gaule Romaine. Lille: Association Revue du Nord. pp. 23-50. 
How to cite this article: Bevan, A 2019 A Stored-Products Revolution in the 1st Millennium BC. Archaeology International, 22(1), pp. 127-144. DOI: https://doi.org/10.5334/ai-404

Submitted: 31 July 2019 Accepted: 31 October 2019 Published: 17 January 2020

Copyright: ( 2019 The Author(s). This is an open-access article distributed under the terms of the Creative Commons Attribution 4.0 International License (CC-BY 4.0), which permits unrestricted use, distribution, and reproduction in any medium, provided the original author and source are credited. See http://creativecommons.org/licenses/by/4.0/.

$\mathrm{u}[$ Archaeology International is a peer-reviewed open access journal published by Ubiquity Press. 